University of Michigan Law School

University of Michigan Law School Scholarship Repository

Law \& Economics Working Papers

$3-31-2021$

\title{
Stanley Surrey, The 1981 US Model, and the Single Tax Principle
}

\author{
Reuven S. Avi-Yonah \\ University of Michigan Law School, aviyonah@umich.edu \\ Gianluca Mazzoni \\ The University of Michigan
}

Follow this and additional works at: https://repository.law.umich.edu/law_econ_current

Part of the Law and Economics Commons, Legal History Commons, Public Law and Legal Theory Commons, and the Tax Law Commons

\section{Working Paper Citation}

Avi-Yonah, Reuven S. and Mazzoni, Gianluca, "Stanley Surrey, The 1981 US Model, and the Single Tax Principle" (2021). Law \& Economics Working Papers. 179.

https://repository.law.umich.edu/law_econ_current/179

This Article is brought to you for free and open access by University of Michigan Law School Scholarship Repository. It has been accepted for inclusion in Law \& Economics Working Papers by an authorized administrator of University of Michigan Law School Scholarship Repository. For more information, please contact mlaw.repository@umich.edu. 
DRAFT 3/31/21

\title{
STANLEY SURREY, THE 1981 US MODEL, AND THE SINGLE TAX PRINCIPLE
}

\section{Reuven Avi-Yonah}

\author{
Gianluca Mazzoni
}

\begin{abstract}
2021 marks the $40^{\text {th }}$ anniversary of the 1981 U.S. Model Tax Treaty as well as the $5^{\text {th }}$ anniversary of the 2016 US Model Tax Treaty. The first author has repeatedly argued that the 1981 Model gave life to the single tax principle ("STP"). The 2016 Model updates effectively implemented the principle that cross-border income should be taxed once - that is not more and but also not less than once. For example, the 2016 Model does not reduce withholding taxes on payments of highly mobile income that are made to related persons that enjoy low or no taxation with respect to that income under a preferential tax regime. The aim of this article is to identify with relative certainty the origins of the STP. The purpose is to give a systematic and historical interpretation of the STP by looking at the context during which it was purportedly founded. This article draws extensively on published and unpublished writings of the main architect of US international tax rules, Stanley Surrey, and is the result of archival research conducted at the Historical \& Special Collections of Harvard Law School Library. The aim of this article is to show that the origins of the STP, from the perspective of the United States as a source country, can be traced to the eight-year period from 1961 to 1969 when Surrey, a Harvard law professor (1950-1984) became the first US Assistant Secretary of the Treasury for Tax Policy. As far as tax treaties are concerned, Surrey made two major contributions to applying the STP in practice. First, the tax treaties negotiated by Surrey: (i) the Luxembourg-United States Income and Capital Tax Treaty (1962), (ii) the 1963 protocol to the treaty with the Netherlands applicable to the Netherlands Antilles, and (iii) the Canada-United States Income Tax Treaty (1966) took pains to enforce source-based taxation in cases where there was no residence-based taxation of passive income. Second, it was during Surrey's time at the US Treasury Department that the US delegation wrote two notes to the OECD Fiscal Committee recommending the establishment of a new Working Group which would address the problem of Tax Avoidance through the Improper Use or Abuse of Tax Conventions. This article discusses Surrey's contributions to the practical implementation of the STP.
\end{abstract}




\section{Introduction}

2021 marks the $40^{\text {th }}$ anniversary of the 1981 U.S. Model Tax Treaty as well as the $5^{\text {th }}$ anniversary of the 2016 US Model Tax Treaty. The first author has repeatedly argued that the 1981 Model gave life to the single tax principle ("STP"), because it denied treaty benefits (reduction of withholding taxes) to income that was not fully taxed in the residence jurisdiction. ${ }^{1}$ This provision disappeared from the 1996 and 2006 versions of the US Model, but resurfaced in expanded form in the 2016 version. The 2016 Model updates effectively implemented the principle that cross-border income should be taxed once - that is not more and but also not less than once. For example, the 2016 Model does not reduce withholding taxes on payments of highly mobile income that are made to related persons that enjoy low or no taxation with respect to that income under a preferential tax regime.

The aim of this article is to identify with relative certainty the origins of the STP. The purpose is to give a systematic and historical interpretation of the STP by looking at the context during which it was purportedly founded. This article draws extensively on published and unpublished writings of the main architect of US international tax rules, Stanley Surrey, and is the result of archival research conducted at the Historical \& Special Collections of Harvard Law School Library. The aim of this article is to show that the origins of the STP, from the perspective of the United States as a source country, can be traced to the eight-year period from 1961 to 1969 when Surrey, a Harvard law professor (1950-1984) became the first US Assistant Secretary of the Treasury for Tax Policy. As far as tax treaties are concerned, Surrey made two major contributions to applying the STP in practice. First, the tax treaties negotiated by Surrey: (i) the Luxembourg-United States Income and Capital Tax Treaty (1962), (ii) the 1963 protocol to the treaty with the Netherlands applicable to the Netherlands Antilles, and (iii) the Canada-United States Income Tax Treaty (1966) took pains to enforce source-based taxation in cases where there was no residence-based taxation of passive income. Second, it was during Surrey's time at the US Treasury Department that the US Delegation wrote two notes to the OECD Fiscal Committee recommending the establishment of a new Working Group which would address the problem of Tax Avoidance through the Improper Use or Abuse of Tax Conventions. This article discusses Surrey's contributions to the practical implementation of the STP.

\section{Luxembourg}

The first US treaty which had some indication that double non-taxation of US source income was inappropriate was the treaty with Luxembourg, concluded in 1962, which precluded the application of reduced US withholding rates to certain Luxembourgian holding corporations that were not subject to tax on a residence basis.

\footnotetext{
${ }^{1}$ Avi-Yonah, Who Invented the Single Tax Principle? An Essay on the History of US Treaty Policy, 59 NYLS L Rev 305 (2015). See also, Full Circle? The Single Tax Principle, BEPS, and the New US Model (October 13, 2015). 1 Global Tax'n 12 (2016), U of Michigan Public Law Research Paper No. 480, U of Michigan Law \& Econ Research Paper No. 15-019, Available at SSRN: https://ssrn.com/abstract=2673463 or http://dx.doi.org/10.2139/ssrn.2673463. The historical origins of the STP are much older, dating back to the US adoption of the foreign tax credit (instead of an exemption) in 1918 and to the work of the League of Nations in the 1920s. See Mazzoni, Present at the Creation: Archival Research and Evidence on the Origins of the Single Tax Principle, 47 Intertax 813 (2019).
} 
A memorandum from Mr. McGreevy to Mr. Surrey dated October 19, 1962 helps us in reconstructing the original intent of the 1962 treaty with Luxembourg.

The Luxembourg income tax treaty was signed at 12 noon on December 18, 1962 at the US State Department. The signatories were Mr. Rusk (US) and the Luxembourg Ambassador to the United States acting on behalf of the Heads of State of each country. The signing ceremony was open to the public and held in the Diplomatic Reception Room in the New State Building, $7^{\text {th }}$ floor, opposite the Secretary's office. The negotiations of the Luxembourg treaty were overseen by Surrey with the help of Mr. Tillinghast, Mr. Gordon and Mr. McGreevy.

Article XV of the 1962 tax convention with Luxembourg was directed primarily at Luxembourg "holding companies" as defined under then existing Luxembourg law. Such companies were exempt from income, property and trade taxes on their dividend income from all sources provided that they did not engage in trade or business. In addition, nonresident shareholders (corporate and individual) were not subject to Luxembourg tax on income from a Luxembourg holding company. Article XV rendered the provisions of the tax convention inapplicable to income of Luxembourg "holding companies" or to income derived therefrom by their shareholders.

At that time, Luxembourg did not grant similar benefits to operating companies. The Luxembourg income tax structure was similar to that of Germany and the Netherlands. All three countries taxed the global income of an operating corporation having a domestic seat of management but made special provision for intercompany dividends. Each country exempted from tax a dividend received by a domestic corporation from a domestic subsidiary in which the recipient held a "substantial interest" (defined in each country as 25 percent of the stock of the subsidiary). However, only the Netherlands then exempted from tax dividends from a foreign subsidiary in which a domestic parent held a "substantial interest." A nonresident shareholder (corporate or individual) was subject to withholding tax on dividends from an operating corporation under the laws of each of these three countries.

During the 1962 negotiations with Luxembourg, the Luxembourg delegation expressed concern that the draft of Article XV proposed by the United States would have denied reduced treaty rates of tax on dividends received by a Luxembourg operating corporation from a US corporation in which it held a "substantial interest" in the event that Luxembourg should have amended its laws to extend the exemption privilege to dividends received from a foreign subsidiary. When the US delegation asserted that this would have been the case, the proposed draft was termed "unacceptable" by Luxembourg.

Telegram no. 978, dated October 2, 1962, from Walter Cecil Dowling, US Ambassador to West Germany from 1959 to 1963, to the US Secretary of State well described the situation:

"Agreement not yet reached with Luxembourg. US proposal for modification of Article XV (holding companies) of Draft Convention as contained in Gordon letter to Schaus August 6, 1962 not acceptable to Luxembourg. Their argument was that language too broad and might deny benefits of treaty to any operating Luxembourg corporation exempted from tax on dividends from a foreign subsidiary or on other income from foreign sources such as sales income. Such exemption not now granted but Luxembourg may want to change its laws to do so. Acceptance of Luxembourg proposal would mean US acquiescence in a new "Swiss tax haven." New US alternative being considered by Luxembourg. Expect their reaction Thursday. 
McGreevy returning Washington Monday or Tuesday. Hope to have agreed draft then."

Because of pressures for immediate agreement on a tax convention with Luxembourg, the US delegation proposed to add a new sentence to the draft of Article XV, which was deemed acceptable to Luxembourg:

"The expression 'substantially similar benefit' shall be deemed not to include tax reduction or exemption granted to any corporation in respect of dividends derived from another corporation, 25 percent or more of the stock of which is owned by the recipient corporation."

This last sentence in effect provided that the tax convention would have applied even though Luxembourg law exempted from all taxes dividends received by a Luxembourg operating corporation from a US corporation in which it held at least 25 percent of the stock.

Article XV clearly denied reduced treaty rates on dividends received by an operating corporation on its portfolio investments (less than 25 percent holdings) if Luxembourg law subsequently were amended to exempt such income from tax or if the domestic tax rate on such income were substantially reduced. If Luxembourg law should have later provided that dividends received by a nonresident shareholder from a Luxembourg operating corporation were exempt from tax, then the United States should have been free to maintain that reduced treaty rates for dividends from US sources were inapplicable with respect to such a corporation since the amendment relating to the Luxembourg withholding rate of tax on shareholders was "substantially similar" to a benefit conferred under the holding company laws and no exception was provided for this type of benefit under Article XV.

The concession made to Luxembourg was intended to be restricted to the hypothetical presented. Moreover, the Luxembourg delegation insisted that there were no plans then to extend tax exemption to dividends received from a foreign subsidiary. It was believed that such a change in Luxembourg should have not caused undue embarrassment to Treasury in view of the fact that similar provisions in Dutch and Canadian law had not prompted special recognition in US tax treaties with the Netherlands or Canada. The draft of Article XV actually had gone further than a comparable provision imposed by Germany in its treaty with Luxembourg in that it would have applied to portfolio income of an operating company to which holding company benefits were conferred. The potential for abuses in the event of such a change appeared to be limited, particularly when the Luxembourg corporation had US shareholders. Distributions to US shareholders would have been taxable in the United States and the exemption from Luxembourg tax on the corporation's dividend income would have reduced the foreign tax credit claimed there. Accumulations of the dividend income in Luxembourg corporation would have been possible but US shareholders would have had to consider the implications of personal holding company tax, tax on foreign personal holding company income and section 12 of the Revenue Act of 1962 if the stock of the Luxembourg corporation were closely held by US shareholders. Even if the stock were widely held, a foreign corporation with US citizens as shareholders which had US source income would have been technically subject to accumulated earnings tax in the United States although the likelihood of collecting such a tax seemed remote.

The Luxembourg delegation was well aware of the attitude of the United States regarding the use of tax treaties by its treaty partners to enhance their reputations as tax havens. Perhaps the chief restraint against prospective legislation by Luxembourg to permit treaty abuses was the power of the United States to terminate the tax convention. It may be that the 5-year interval imposed by Article XIII before this power might have been exercised unilaterally was too long 
under the circumstances. However, in view of Luxembourg's desire for a US tax convention, it seemed reasonable to assume it would have adhered to the spirit as well as the letter of the agreement.

In summary, the 1962 treaty with Luxembourg was the first one where the US adopted a so-called "preferential tax treatment" approach according to which certain convention benefits are denied to any entity which by virtue of "special measures" is subject to taxation on the benefited income at rates substantially lower than those generally applicable in the State in which the entity is organized, if the entity is owned to a substantial extent by persons not entitled to the benefits of the convention. After 1962, subsequent provisions generally were drafted along the following lines:

"If 25 percent or more of the capital of a company which is a resident of a Contracting State (e.g., Luxembourg) is owned directly or indirectly by individuals who are not residents of that State (Luxembourg), and if by reason of special measures the tax imposed by that State (Luxembourg) on that company with respect to dividends, interest or royalties arising in the other Contracting State (e.g., United States) is substantially less than the tax generally imposed by the first-mentioned State (Luxembourg) on corporate business profits, then notwithstanding the provisions of Articles 10,11 or 12 , that other State (United States) may tax such dividends, interest or royalties."

According to Surrey, the theoretical justification behind such provisions was that if preferential measures substantially mitigate taxation by the State of residence, e.g., Luxembourg Law of July 31, 1929, and Decree Law of December 27, 1937, then there is little danger of double taxation, and cession by the United States, as a source country, of its right to tax is not appropriate.

A memorandum to the attention of Mr. Surrey, The Secretary, Mr. Deming, and Mr. Knowlton, dated December 5, 1966, about the establishment of a new Luxembourg Investment Fund briefly describes a situation behind the denial of treaty benefits under article XV of the 1962 with Luxembourg:

"Michael Belmont, a member of the British firm Cazenove \& Co., told me Friday that his firm, together with another British firm, are acting as managers in the formation of a Luxembourg Investment Fund. This Fund, which will be open only to non-Americans, will invest exclusively in US securities. The United States Trust Company will be the investment advisor. The initial offering is for $\$ 20$ million and it will operate as a closed-end Fund. If all goes well, the capitalization will be increased. The shares of the mutual fund will be quoted on European exchanges. Shares may be redeemed at net asset value. The Fund will concentrate on capital appreciation.

Incidentally, under our treaty with Luxembourg the withholding tax on dividends will be at 30 percent rather than the reduced rate otherwise applicable to Luxembourg, since Luxembourg will not tax the income. Our income tax will not be an adverse factor. The shareholders in the Luxembourg Fund will, of course, not be subject to US tax. The capital gains of the Fund will not be taxable in the US."

The issue was whether it was appropriate to grant treaty benefits to a Luxembourg Investment Fund which invested exclusively in US securities and by virtue of Luxembourg domestic law was not subject to tax on its US source income in case where the Fund was owned to a substantial extent by third-country residents, i.e. persons not entitled to the benefits of the US-Luxembourg tax treaty. It is our opinion that for Surrey \& co. it was inappropriate for the United States to forego its taxing jurisdiction in such case. 
Interestingly, the US official explanation proposed by the US Treasury Department stated that although the preferential tax treatment approach was not found in any income tax convention concluded by the United States ... certain precedent may be found in some of the relief provisions contained in the conventions with the United Kingdom, Ireland, Australia, and Pakistan requiring

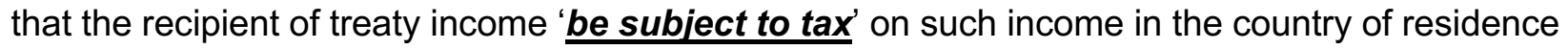
in order to qualify for exemption from, or reduction in the rate of, the tax of the country of source. The US official explanation also stated that Article XV was consistent with the spirit of the provisions of section 12 of the Revenue Act of 1962 relating to the taxation of certain "tax-haven" income of controlled foreign corporations ("CFCs") to US shareholders. In our opinion, this last sentence is a clear and undeniable indication that Surrey wanted to close the loopholes of US international tax rules by adopting both a top-down (introducing Subpart $F$ legislation dealing with the issue of base companies from the perspective of residence country) and a bottom-up approach (introducing Limitation on Benefits ("LOBs") provisions dealing with the issue of conduit companies from the perspective of source country).

To be intellectually honest, however, Surrey was not the first one at the international level who adopted a preferential tax treatment approach dealing with the issue of conduit companies. Indeed, such approach had already been adopted by the Federal Republic of Germany in the final protocol to the tax convention concluded with Luxembourg in 1958:

"The Convention shall not apply to holding companies within the meaning of the special Luxembourg laws (currently the Acts of July 31, 1929 and December 27, 1937). Neither shall it apply to income derived from such holding companies by a resident of the Federal Republic of Germany or to share in such companies belonging to such persons."

At the domestic level, while the 1962 treaty with Luxembourg gave birth to the principle that international income should pay tax at least once, early instances can be found in the subject to tax clauses of the treaties with United Kingdom, Ireland, Australia, and Pakistan as well as in Article 18 of the 1955 treaty with Italy according to which:

"Each country may collect taxes governed by the conventions which are applied in the other country, in such a manner as to prevent exemptions and reductions of rates granted by the other country under the treaty from benefitting persons who are not entitled to them."

\section{Netherlands Antilles}

Similar language to Article XV of the 1962 treaty with Luxembourg appears in the 1963 protocol to the treaty with the Netherlands applicable to the Netherlands Antilles. See Article I paragraph 1 of the Protocol to the 1948 Treaty (1963) with the Netherlands:

"Articles VII, VIII, and IX of the Convention shall not apply to income derived from sources within the United States by any investment or holding company, corporation, limited partnership or other entity entitled to any of the special tax benefits provided under Article 13, Article 14, or Article 14A of the Netherlands Antilles' National Ordinance on Profit Tax of 1940, as in effect on September 1, 1963, or to substantially similar tax benefits granted under any law of the Netherlands Antilles enacted after such date."

However, the scope of the Antilles provision was limited by an agreement that an Antilles company could entitle itself to treaty benefits by electing to be subject to a low 15 percent tax at residence, or if the Antilles company owned 25 percent of the US payor. See Article I paragraph 2 of the Protocol to the 1948 Treaty (1963) with the Netherlands: 
"Notwithstanding the provisions of paragraph (1) of the present Article, Articles VII, VIII and IX of the Convention shall continue to apply to dividends, interest, and royalties derived by any entity, to which the provisions of paragraph (1) of this Article would otherwise apply, if either

(a) the payer of such income is a United States corporation (other than a United States corporation, 60 percent or more of the gross income of which is derived from interest except to the extent derived by a corporation the principal business of which is the making of loans, dividends, royalties, rents from real property, or gain from the sale or other disposition of stock, securities, or real property), 25 percent or more of the stock of which is owned by such entity; or

(b) all of the stock of such entity is owned

(i) solely by one more individual residents of the Netherlands Antilles in their individual capacities,

(ii) solely by one or more individual residents of the Netherlands in their individual capacities, or

(iii) solely by one or more corporations of the Netherlands."

A memorandum from Surrey, attached to a letter that Douglas Dillon sent on September 19, 1962, to the Honorable J.W. Fulbright, Chairman of the Committee on Foreign Relations United States Senate, gives us some of the background which led up to the negotiations for revisions in the U.S.-Netherlands income tax convention as it applies to the Netherlands Antilles.

In the seven years between 1955 and 1962, the Netherlands Antilles had earned a widespread reputation as a "tax haven," with laws specially designed to take full advantage of the treaty relationship with the United States. An investment company formed in the Netherlands Antilles was then taxed at a maximum rate of 3 percent on its dividend, interest and royalty income from foreign sources, a 90-percent reduction in the corporate tax rates applicable to a Netherlands Antilles operating company. As an inducement to the formation of investment companies, Netherlands Antilles law guaranteed that this reduced rate would not have been increased prior to 1968. A nonresident shareholder of an investment company did not pay any Netherlands Antilles tax on his dividends from the investment company.

As a result of this favorable tax atmosphere, individuals residing in countries which did not have income tax conventions with the United States had been forming investment companies in the Netherlands Antilles to hold their US investment and to collect dividends, interest and royalties from US sources on their behalf. As of January 1, 1962, there were 901 nonresident-owned investment companies incorporated in the Netherlands Antilles. The extent to which the bilateral tax treaty had been utilized by residents of third countries to invest in the United States had not been intended by the Treasury when coverage under the tax convention had been extended in 1955 to the Netherlands Antilles. In addition, the possibility that the United States might have been indirectly encouraging Latin Americans to hold US investments in this manner in conflict with the goals of the Alliance for Progress program had to be considered. ${ }^{2}$ It was for

\footnotetext{
${ }^{2}$ See letter from Surrey to Honorable Jacob K. Javits United States Senate dated June 8, 1962, at p. 1: "I recognize that there is a desire on the part of some Latin Americans to seek safety for their capital from political and economic instability and therefore they invest capital outside their own countries. Nevertheless, in view of our objective under the Alliance for Progress, it seems inconsistent for the United States to give even the appearance of stimulating an outflow of capital from Latin America to the United States through a tax inducement granted by way of a convention with the Netherlands Antilles. Even if termination of the convention would not add to the volume of investment in Latin America, it might still be judicious to terminate it and avoid criticism from Latin American countries."
} 
these reasons that the Treasury initiated discussions with representatives of the Netherlands and the Netherlands Antilles during the spring of 1962 regarding the continued extension of the tax convention to the Netherlands Antilles.

When it had been announced that these discussions would have taken place, Mr. Angulo ${ }^{3}$ and several other attorneys representing Netherlands Antilles investment companies and a few US banks advised the Treasury of their belief that a termination of the tax treaty relationship with the Netherlands Antilles might have resulted in substantial liquidations of US investments held by Netherlands Antilles companies which in turn could have caused adverse balance-of-payments repercussions for the United States. ${ }^{4}$

Several conferences were held to explore that contention and it was established that their primary concern regarding termination of the tax convention as extended to the Netherlands Antilles was the possible elimination of Article XII of the convention because of section $861(a)(2)(B)$ of the Internal Revenue Code.

Section $861(\mathrm{a})(2)(\mathrm{B})$ of the Code provided that a proportionate part of a dividend from a foreign corporation which derived more than 50 percent of its gross income from US sources was also income from US sources. Article XII of the convention rendered this provision of the Code ineffective for foreign shareholders by providing that the United States should have not taxed dividends from a Netherlands Antilles corporation unless the recipient were a citizen, resident or corporation of the United States. The Angulo group maintained that, without the insulation from US tax provided by Article XII, a Netherlands Antilles investment company which derived more than 50 percent of its gross income from US sources would have been forced to liquidate a portion

\footnotetext{
${ }^{3}$ Charles Angulo was born Nov. 4, 1890, in Havana, Cuba. He earned his A.B. from Georgetown University in 1911. He graduated from Columbia Law School in 1914 and immediately after became an associate at the New York law firm of Geller, Ralston \& Blanc, later to become Angulo, Cooney, Marsh \& Ouchterleney. In 1960, Mr. Angulo became special counsel to the New York law firm of Debevoise \& Plimpton f/k/a Debevoise, Plimpton, \& McLean. He retired from the active practice of law in 1964, and his home in Charlottesville, Va. where he passed away on January 11,1972 at the age of 81. See https://www.nytimes.com/1972/01/11/archives/charles-angulo-81-lawyer-since-i914.html

${ }^{4}$ See memorandum from McGreevy to Surrey, Mr. Gordon and Mr. Harley re The Netherlands Antilles dated June 6, 1962, at p. 1: "On June 5, $1962 \mathrm{Mr}$. Gordon and Mr. McGreevy met with the following individuals to continue discussions of the extension of the Netherlands tax convention to the Netherlands Antilles: (i) Charles Angulo - Special Counsel, Debevoise, Plimpton \& McLean (NY); also representing Netherlands Antilles Mutual Funds NV (The First National City Trust Co.); (ii) Kenneth W. Bergen - Bingham, Dana \& Gould (Boston) representing Old Colony Trust Co., Investment advisor in US to Bankers International Investment Co. NV; (iii) Edward M. de Castro - Emmet, Marvin \& Martin (NY); also representing Fahnestock \& Co. and Bank of New York; (iv) William G. Kaelin - Kramer, Marx, Greenlee \& Backus; also representing American Investment Trust NV; and (v) Phillip S. Trenboth - Schroder Trust Co; also investment advisor to American Investment Trust NV. The meeting lasted approximately two hours and the major portion of the meeting was devoted to a rehash of the balance of payment arguments made at the conference of May 10 which were summarized in a memorandum from McGreevy dated May 11 and in a memorandum submitted by Mr. Angulo on May 28, 1962."
}

See Memorandum as to Adverse Effect on our Balance-of-Payments Deficit of Terminating our Income Tax Treaty with the Netherlands Antilles submitted by Charles Angulo on May 28, 1962 at p. 5: “... It has been estimated that Netherlands Antilles investment companies today hold between $\$ 500,000,000$ and $\$ 750,000,000$ of U.S. dollar securities ... Let us take the mean of these two figures, namely, $\$ 625,000,000$, as being the present total holdings in American securities of Netherlands Antilles investment companies. Therefore, upon the cancellation of the Treaty with the Netherlands Antilles, these Netherlands Antilles investment companies, in order to avoid the impact of Section 861(a)(2)(B) and thus to avoid the second tax mentioned above, will have to shift more than $\$ 300,000,000$ from American investments to foreign investments. Thus the balance-of-payments deficit which our Secretary of the Treasury sought to reduce at the bankers' meeting in Rome by $\$ 150,000,000$ would be increased by over twice that amount by virtue of his purely voluntary and avoidable action in canceling the said Netherlands Antilles Treaty."

See also memorandum from Mr. McGreevy re Effect on US Balance of Payments if Extension of US-Netherlands Tax Convention to Netherlands Antilles is Terminated dated May 11, 1962. 
of its investments in the United States to avoid the threat of a second US tax of 30 percent on dividend which it paid to its shareholders.

The amount of US investments which allegedly would have been liquidated and reinvested elsewhere to escape this result was estimated to be between $\$ 250$ and $\$ 300$ million. As Mr. Angulo indicated in his memorandum, the sole basis for this estimate was a report that the investment companies held US investments valued at more than $\$ 500$ million. The source of the report was the Tax Department of the Netherlands Antilles government which calculated the total from tax returns filed in the Netherlands Antilles by all nonresident-owned investment companies for the year 1960. Mr. Angulo arbitrarily liquidated one-half of this total to reach his estimate. However, as argued by Surrey, it was somewhat misleading to assume, as Mr. Angulo did, that more than 50 percent of these US investments would have been liquidated and reinvested in other countries in order to avoid a second US tax on dividends paid by a Netherlands Antilles company to its shareholders. Such an estimate ignored (i) investments which the Netherlands Antilles company might already have had outside of the United States and, more important, (ii) disregarded the fact that section 861(a)(2)(B) of the Code applied only to a foreign corporation which received at least 50 percent of its gross income from US sources. ${ }^{5}$ According to Surrey, the value of the assets held in the United States was not really pertinent to this issue. ${ }^{6}$

Nevertheless, at the Treasury's request, the Netherlands Antilles government provided additional computations which had been compiled from the tax returns of the investment companies. The Netherlands Antilles investment companies reported worldwide investments valued at $\$ 918$ million for the year 1960 . Of this amount, $\$ 574$ million or 62,52 percent represented investments in the United States and $\$ 344$ million or 37,47 percent represented investments in other countries. ${ }^{7}$ According to Surrey, on the basis of these figures, a shift of $\$ 116$ million, and not of $\$ 300$ million, invested in US securities to investments outside of the United States would have been required to produce in the aggregate the balanced investment portfolios which Mr. Angulo claimed would have been needed.

The significant comparison for purposes of section $861(a)(2)(B)$ of the Code was the ratio of gross income from US sources to gross from non-US sources. The compilations of the Netherlands Antilles government indicated that the investment companies reported for 1960 gross income from US sources of $\$ 24$ million and net income after US withholding of $\$ 23$ million. Gross income from sources outside of the United States was not reported but net income was $\$ 19$ million. Inasmuch as the Netherlands Antilles had only one other income tax treaty, that with the United Kingdom, it could have been assumed that the percentage of tax withheld on non-US source income had been at least as severe as US withholding. Moreover, subsequent discussions regarding these computations with representatives of the Netherlands Antilles government established that their figures for US source income of the investment companies included substantial amounts which would not have been regarded as US source income. The

\footnotetext{
${ }^{5}$ See memorandum from Mr. McGreevy to Surrey re Netherlands Antilles dated June 15, 1962, at p. 8.

${ }^{6}$ See memorandum from Mr. McGreevy to Surrey re Netherlands Antilles dated June 18, 1962, at p. 1: "the value of the underlying assets of the investment companies is not really material in determining whether termination of the treaty extension would force the investment companies to liquidate part of their US investments to avoid a secondary US tax on their shareholders. The liability of shareholders of a foreign corporation for this secondary tax depends on whether 50 percent of its gross income is from US sources. However, the market value of any investments which might be liquidated and reinvested outside the United States is material from the standpoint of balance-of-payments repercussions."
}

${ }^{7}$ Id. 
Treasury's analysis of all of the latest statistical data available indicated that the gross income from US sources of the Netherlands Antilles investment companies was approximately one-half of the gross income of these companies from all sources. It was recognized that this ratio might not have held constant from company to company and that there might have been a potential threat of secondary tax liability in specific instances if the extension of the tax convention had been terminated. However, according to Surrey, it seemed demonstrably clear that the substantial liquidation of US investments envisioned by Mr. Angulo as a necessary concomitance of termination was not supported by objective evidence.

While the Treasury did not propose to terminate the tax treaty relationship with the Netherlands Antilles, ${ }^{8}$ the decision had been made to make formation of nonresident-owned investment companies in the Netherlands Antilles to hold US investments less attractive. Under the agreement reached with representatives of the Netherlands Antilles government on June 25, 1962 the US tax rates on dividends, interest and royalties paid to these companies would have been increased to 30 percent. ${ }^{9}$ This is the same tax rate which is now imposed on these types of income when paid to an investment company incorporated in a country which does not have a tax treaty with the United States. This rate also compared favorably to the total tax burden on a dividend from US sources paid to an investment company incorporated in any other country with which the United States had a tax treaty because of the additional taxes which would have been imposed by that country on the income of the company or on the dividends it paid to its

\footnotetext{
${ }^{8}$ In a memorandum to the attention of Surrey, dated June 21, 1962, Mr. Gordon stated that termination of the reduced rates would, from the United States point of view, have had the following consequences: (1) a revenue increase, on the assumption that no change were to be made in the volume of investments in the United States by Netherlands Antilles investment and holding companies, of about $\$ 4.1$ million; (2) an indication of the seriousness with which the United States considered the tax avoidance problem and a demonstration to other countries of its plan to eliminate existing tax avoidance opportunities; and (3) removal of possible grounds for criticism by Latin American countries that the United States was encouraging the movement of capital from Latin-America into the United States.
}

See also supra note 2 at p. 4 "... On the other hand, for what it is worth I am beginning to reach a conclusion for the first time that a termination of this extension would have an immediate adverse effect on our balance of payments. For this reason and because there seems to be a desire in the Netherlands Antilles to maintain the extension for legitimate purposes, I would urge revision rather than termination of the extension if at all possible from a policy viewpoint."

See also memorandum from Mr. McGreevy to Surrey, Mr. Gordon and Mr. Harley re The Netherland Antilles and The Netherlands Tax Convention dated June 1, 1962 at p. 1: "... It appears now ... that we probably will not terminate in view of a change in position on the balance of payments issue conveyed by Mr. Bergen on behalf of the group we met with on May 10."

${ }^{9}$ In a memorandum to the Secretary dated August 30,1962, Surrey stated that the modifications agreed upon were actually proposed by Mr. Angulo who maintained that no balance-of-payments repercussions would follow.

See also supra note 2 at p. 3: "We also discussed briefly the suggestion, first made by Mr. Bergen and here tendered by Mr. Angulo, that this group might find palatable 30 percent withholding on all passive income of the investment companies from the United States if Article XII of the convention, providing insulation from a US secondary tax, was retained in force. It seemed to be acceptable although Mr. de Castro thought 27 percent more equitable in view of the tax burden on a Canadian NRO corporation and Mr. Trenboth, who did not seem at all surprised, said this was a new proposal to him and he would have to think about it. Mr. Gordon made it clear, however, that this was their proposal and not Treasury's."

See also memorandum from Mr. McGreevy to Surrey, Mr. Gordon and Mr. Harley re The Netherland Antilles and The Netherlands Tax Convention dated June 1, 1962 at p. 2: "... On May 31 Mr. Bergen indicated that he had conferred with his colleagues and that they would not object to an increase in tax rates applicable to Netherlands Antilles investment companies although there is some resistance to the 30 percent rate. Mr. Angulo feels that the rate should be 25 percent so that it would not be more advantageous to use a Canadian NRO company. I reminded Mr. Bergen of Canadian succession duties and he agreed that this would be an offsetting factor. Mr. Bergen does feel that the ultimate tax burden on a shareholder of an investment company in the Netherlands Antilles should not be higher than in any other treaty country if they are to have success selling their mutual fund shares. He inquired about the Swiss situation and I explained that the potential tax burden seemed much heavier on a Swiss investment company but that we did not know what arrangements might be possible at the administrative level. He does not know either and I suggested that any information which his group could supply along these lines would be helpful." 
shareholders. No changes in Article XII of the tax convention had been contemplated so Mr. Angulo's concern with respect to the applicability of section $861(\mathrm{a})(2)(\mathrm{B})$ of the Code was relieved.

Surrey anticipated that the effect of this agreement would have been to discourage considerably further incorporations of nonresident-owned investment companies in the Netherlands Antilles to make investments in the United States but that liquidations of US investments held by companies then in existence would have been nominal since withholding rates of tax on dividend income from most European countries were comparable to the statutory rate imposed by the United States. ${ }^{10}$ Mr. Angulo and others who had originally opposed any changes in the tax convention as applied to the Netherlands Antilles had advised the Treasury that they would have joined in these conclusions. Similar opinions were also expressed by the representatives of the Netherlands Antilles government. Therefore, Surrey believed that the agreement reached in June of 1962 to modify the tax convention as applied to the Netherlands Antilles provided a satisfactory compromise to a potentially difficult situation. ${ }^{11}$

The above archival research shows that during negotiations with representatives of the Netherlands and of the Netherlands Antilles in March of 1962, the United States indicated that it was considering exercise of the right under Article XXVII(3) of the US-Netherlands income tax convention to unilaterally terminate the territorial extension to the Netherlands Antilles. However, when it became publicly known that the United States were considering termination of the extension, representatives of several New York banks and investment brokers requested a hearing to present their view that this would have resulted in a substantial portion of the capital investment of the Netherlands Antilles investment companies in the United States being liquidated for reinvestment in other countries.

Interestingly, it should be noted that while, as argued by Fishbien, seven internal Treasury Department reports unequivocally support the notion that the idea behind Subpart $F$ was initially formed mainly due to the deteriorate US balance of payment position, ${ }^{12}$ here, the balance of payment argument was used by lobbyists to stop Treasury from terminating the tax treaty relationship with the Netherlands Antilles. We are not going to argue whether Angulo group's arguments made sense economically. However, we just wanted to note that the US-Netherlands Antilles Treaty was eventually terminated in 1987 and during these 24 years taxpayers had enough time to relocate their investment and holding companies in more favorable tax jurisdictions.

\section{Canada}

\footnotetext{
${ }^{10}$ See supra note 2 at p. 6 . McGreevy thought that it was unreasonable to assume that a tax rate increase alone would have prompted a substantial liquidation of these investments. Withholding rates in Europe generally approached the 30 percent statutory rate applicable in the United States on dividends. Other factors such as stability, growth potential and marketability of equity securities must be considered. If US corporate stocks no longer offered advantages when measured by these factors, then some liquidations must be expected. But the cause would not have been an increase in the rate of US tax on dividends alone.

${ }^{11}$ See memorandum from Mr. McGreevy to Surrey, Mr. Gordon and Mr. Harley re The Netherland Antilles and The Netherlands Tax Convention dated June 1, 1962 at p. 3 "In the event that a decision is reached to revise the Netherlands Antilles extension to provide for increased tax rates on passive income of investment companies, this probably should be discussed with representatives of the Netherlands Antilles prior to June 30 and perhaps an informal agreement reached. It seems almost certain that such a compromise would be acceptable as an alternative to termination. As a matter of fact, during the negotiations with the Dutch which Mr. van Werkhoven attended, this was the solution which all understood was probably the best we could offer."
}

${ }^{12}$ Fishbien, From Switzerland with Love: Surrey's Papers and the Original Intent(s) of Subpart-F (June 20, 2018). Virginia Tax Review, Vol. 38, No. 1, p. 1 (2018), Available at SSRN: https://ssrn.com/abstract=3200439 
Here, a review of Surrey's Papers on the tax treaty with Canada from 1964 to 1965 shows an interesting letter that Surrey had sent to Marshall J. Langer ${ }^{13}$ on February 27, 1965. Surrey acknowledged receipt of Langer's letter of February 8, 1965 enclosing a copy of a request for ruling submitted to the Commissioner of Internal Revenue. Surrey stated that he was quite interested in Langer's request and wanted to let Langer know that if and when the Treasury would have discussed with the Canadian Government changes in the convention between the United States and Canada, US Treasury would have requested Canada to amend Article XI of that convention so as to make its benefits available only to resident Canadian corporations.

We were not able to locate neither Langer's letter to Surrey of February 8, 1965 nor copy of a request for ruling that Langer submitted to the Commissioner of Internal Revenue and attached to his letter to Surrey. Previous papers show that on February 26, 1965 Mr. Loengard and Surrey discussed Langer's letter of February 8, 1965 whereby Mr. Loengard stated that Canada did not have any discretion as far as he knew; i.e., they could not levy a tax on a nonresident company. In addition, according to Mr. Loengard, neither the United States had discretion under the treaty to levy a withholding tax on payments made to a nonresident Canadian company. Finally, Mr. Loengard concluded his letter to Surrey stating that it was Nate (Gordon?)'s opinion to only take this matter up with Canada when the Treasury was ready to renegotiate the treaty generally.

A couple of weeks later, on March 17, 1965, Surrey sent to the Secretary a memorandum attaching a proposed press release announcing that action would have soon been taken to close a tax loophole arising out of a combination of Canadian law and the United States - Canadian income tax treaty.

Under that treaty, a reduced US withholding tax applied to income paid to a corporation created under the laws of Canada. However, under Canadian law no tax was imposed on a company created in Canada if it was managed and controlled abroad. It appeared to Surrey that such companies were then being organized with management and control in Bermuda, the Bahamas and other tax haven countries that levied no tax on a company that was managed and controlled there. The result was that third-country nationals were beginning to take advantage of a loophole similar to that of the Netherlands Antilles.

Surrey was indicating that they had discussed the problem with the Canadians and received a positive initial reaction for doing something. But in order to obtain a firmer commitment, they agreed to prepare a press release which the US Embassy in Ottawa would have cleared with the Canadians before they issued it. Surrey also stated that they had left open the possibility of having the tax loophole closed by unilateral Canadian action, since revision of the tax treaty might have been too time-consuming.

Surrey concluded the memorandum by stating that the matter had been called to his attention by a group of practitioners which had been planning to form such a Canadian

\footnotetext{
${ }^{13}$ Marshall J. Langer was born on May 30, 1928 in Brooklyn, New York. He was the only son of Edna and Samuel Langer. He graduated from the University of Miami Law School summa cum laude in 1951 and practiced law for many years in South Florida and internationally. Among many publications, he co-authored together Edward J. Smith the leading treatise on Practical International Planning in December of 2000, which is currently at its $4^{\text {th }}$ edition. Relevant to our discussion is his article Tax Treaties Creating Tax Haven Situations, Tax Notes Federal, 10/06/1980. In that article, Langer analyzed the factors that make specific tax treaties particularly susceptible to tax haven manipulations. He used the income tax treaty between the United States and the Netherlands Antilles as his principal example. He then turned to an analysis of the US efforts to deal with the question of treaty shopping. He concluded by suggesting that the US position with respect to treaty shopping has not always been consistent, and that treaty shopping would have continued until effective action is taken to stop it.
} 
corporation. The group stated that publication of the press release would have probably ended their plans. The group also thought that there had been some Curacao corporations which had been thinking of shifting to Canada if the Treasury had not taken action of the kind contemplated in the press release.

Consequently, on April 13, 1965, the Treasury published the following press release titled United States to Act Against Tax Avoidance under Canadian Tax Treaty:

"Action will soon be initiated by the United States to tighten the tax rules that apply to income flowing between the United States and Canada so as to eliminate a tax avoidance device which now permits people living outside both countries to receive investment income from the United States at substantially reduced tax rates, the Treasury Department announced today.

This unintended tax preference results from the interaction of existing Canadian law and the provisions of the existing tax treaty between the United States and Canada. The treaty provides that a company organized in Canada and receiving investment income from the United States is subject to a 15 percent US withholding tax on such income rather than the usual 30 percent. However, Canadian law provides that a company organized under Canadian law but deriving its income from outside Canada shall be exempt from Canadian taxes if the company is managed and controlled outside Canada. The combination of these provisions makes it possible for such a Canadian company to be used by third country residents as a device to avoid US taxes.

A holding company, a mutual investment fund, or a similar investment company created under Canadian law but managed and controlled in a "tax haven" country may be used to make investments in the United States by people living in countries that have no tax treaty with the United States. Such people can derive investment income subject only to a 15 percent withholding tax in the United States and to no tax whatsoever in either Canada or their home country.

A modification of the income tax treaty between the United States and the Netherlands last year led to elimination of the Netherlands Antilles as a place through which third country residents could similarly avoid taxes on investment income. As a result Canadian corporations may now be in the process of being established for the same purpose.

It is anticipated that discussions will be held soon with the Canadian authorities to consider appropriate measures to eliminate the tax avoidance described."

Meanwhile, on the other side of the border, the Canadian government had already taken steps to do its own plugging of this loophole. The fiscal 1966 budget submitted to Parliament by Finance Minister Walter Gordon contained a provision for taxing corporations which incorporated in Canada and then moved their headquarters outside the country. If this provision had been adopted, such corporations would have, in the future, been considered resident in Canada for purposes of Canadian tax.

An undated memorandum from Mr. Gordon to Surrey and Mr. Loengard clarified the Canadian budget proposal. According to Mr. Gordon, the proposed change in the definition of a Canadian resident corporation to include all companies incorporated in Canada, whether or not their management and control was in Canada, would have applied to all companies incorporated in Canada after April 26, 1965. Those companies incorporated in Canada prior to that date, which were managed or controlled outside Canada, would, in the future, have been treated as Canada only if they were actually resident in Canada during the taxable year which included April 26,1965 , or if they became resident during any year subsequent to this year. Thus a company which was incorporated in Canada prior to 1865 and which continually had its management 
and control outside Canada in every year from 1965 on, would have not been treated as a Canadian resident company. If it became resident in 1965, or in any later year it would have continued to be treated as a resident company in all years subsequent to that year. In other words, the Canadian domestic law would have exempted a Canadian company from tax on income originating outside Canada if the company had been incorporated before April 26, 1965, and had not been a resident corporation in any year ending after that date. According to Gordon, the unintentional result had been to allow such a Canadian company to be used by third-country residents as a device to avoid US taxes. Therefore, Treasury considered a supplementary tax convention designed to remove this unintended tax benefit. On October 25, 1966, a new paragraph 6 was added to article XI of the US-Canada Income Tax Treaty of 1942:

"Paragraph 1 of this Article shall not apply in respect of income derived from sources in one of the Contracting States and paid to a corporation organized under the laws of the other Contracting State if such corporation is not subject to tax by the last-mentioned Contracting State on that income because it is not a resident of the last-mentioned Contracting State for purposes of its income tax."

\title{
5. $\underline{\text { OECD }}$
}

As mentioned above, Surrey's ideas were not only implemented at the domestic level within the treaties that he and his squad negotiated with foreign counterparts. His ideas had also a huge impact at the OECD level. Indeed, it was during Surrey's time at the US Treasury Department that the US Delegation wrote two notes to the OECD Fiscal Committee recommending the establishment of a new Working Group which would address the problem of Tax Avoidance through the improper use or Abuse of tax Conventions. In a note written on November 14, 1961, it was stated that:

\begin{abstract}
"In recent years there has developed a problem of tax avoidance and evasion to which it would be appropriate for the Fiscal Committee to address itself. This problem involves the exploitation of tax conventions in a manner which is unnecessary for the avoidance of double taxation and which provides unintended benefits to taxpayers. For example, an enterprise of one contracting country may establish a corporate subsidiary in the other contracting country principally for the purpose of taking advantage of the interaction of domestic tax statutes and an income tax convention between the two countries in such a way as to reduce the aggregate of taxes paid to a level below that which would prevail if the activities were conducted entirely in either one of the countries party to the convention. A further example is the establishment of a similar subsidiary by an enterprise of a third state in order to take advantage of the treaty between the two contracting states... It is the view of the United States Delegation that income tax conventions should be so constructed that they cannot be availed of to avoid legitimate tax burdens, that artificial transactions and business structures entered into or established to avoid legitimate tax burdens should be discouraged and prevented, and that international co-operation to this end is possible and necessary." 14
\end{abstract}

The establishment of a Working Party was further recommended by the United States Delegation in a second note of January 4, 1962, where it was stated that:

"... Developments in recent years, however, suggest that income tax conventions must also deal with the problem of legal avoidance of tax achieved through what many regard as abuse of tax conventions. The experience of the United States, as well as of other countries, has shown that in many cases the tax conventions have been employed for purposes other than the intended

\footnotetext{
14 OECD Fiscal Committee, Note by the United States Delegation on Tax Avoidance through the Improper Use or Abuse of Tax Conventions (14 Nov. 1961), TFD/FC/135, available at http://www.taxtreatieshistory.org/
} 
objective of eliminating double taxation, and have served as a means by which taxpayers avoid their proper tax burdens. Through the establishment of related corporations in several countries, often for no purpose other than the anticipated tax benefits, taxpayers in treaty countries have taken advantage of international tax agreements and the interaction between such agreements and internal laws so as to subject their total profits to taxes far below those imposed on purely domestic enterprises in any one of the countries in which these inter-related companies are created. Moreover, residents of non-treaty countries have been able to obtain the benefits of the conventions between two treaty countries by forming corporate entities in one or more treaty countries for the sole purpose of obtaining such treaty benefits. In both types of cases, benefits are obtained which were never intended by the Contracting States when the tax conventions were negotiated. The tax avoidance achieved in this manner, legal though it may be, may have serious repercussions. Not only are Governments denied legitimate revenues and inequities created among taxpayers similarly situated, but significant distortions may result in the international allocation of resources..." 15

WP No. 21 on Tax Avoidance was thus created two weeks later on 17 January 1962 after solicitation by the US Delegation. According to the draft terms of reference, WP No. 21 was requested to consider whether, and to what extent, tax avoidance problems have developed through the abuse of tax conventions between member countries and whether the benefits of a convention should and can be denied to certain entities situated in the territories of the signatories to a convention or in the territories of third countries in order to prevent such abuse. Mr. Gordon, Mr. Ross and Mr. Beinert were representatives of the US delegation (Rapporteur of WP No. 21) together with delegates of Denmark.

Here a review of Surrey's Papers shows a report from Surrey to William T. Wolfe dated November 27, 1961 whereby Surrey stated that:

"The Treasury also participated in a meeting of the Fiscal Committee of the OECD and put forward a proposal for the creation of a working group that would examine the tax laws of Member countries to ascertain to what extent they operate, in conjunction with tax treaties, to provide unintended tax benefits and to promote tax avoidance. The working group would also be charged with developing draft provisions for inclusion in tax conventions which would preclude such tax benefits. While sentiment in the Fiscal Committee seemed to favor such a working group, action on its establishment was deferred until the January meeting, by which time the United States delegation will have circulated a proposal reflecting the views expressed at the November meeting."

Of course the views of the US delegation were opposed by the Swiss delegation. From the report on meeting of the OECD Fiscal Committee which was held on January 22-25, 1962 it emerged that it was unnecessary for the Swiss delegation to adopt a special treaty article dealing with abuse of tax conventions. The Swiss delegation noted that Switzerland had modified its tax regulations to prevent abuse of Swiss tax conventions. After an animated exposition of the virtues of Switzerland as a financial, geographic and economic center for international enterprises, and the reasonable level of taxation, the Swiss delegation stated that they did feel that their tax treaties were sometimes used to the advantage of persons not entitled to them and that this was outside the spirit of its tax treaties. Under the new regulations, a foreign-owned Swiss company deriving the bulk of its income abroad which paid out more than half its gross income to foreign enterprises

\footnotetext{
15 OECD Fiscal Committee, Note by the United States Delegation on Tax Avoidance through the Improper Use or Abuse of Tax Conventions (4 Jan. 1962), TFD/FC/136, available at http://www.taxtreatieshistory.org/
} 
in the form of deductible items, such as interest, royalties and fees, would have been considered to be misusing the Swiss conventions. This provision reflected in part the fact that some Swiss tax-haven companies had been paying out virtually all their income as cost items to other related companies in Monaco, Liechtenstein, etc. In addition, foreign-owned companies that did not pay out at least one-fourth of their profits as dividends would also have been considered to be misusing the tax conventions. The consequences of such a finding were not made clear, but the Swiss delegation took the position that its unilateral action had ended the likelihood of tax abuses in Switzerland.

Several delegations welcomed the Swiss action. The Austrian and United States delegations expressed similar views but noted that unilateral was insufficient to deal with the problem. While the Swiss action might have forced tax haven firms to distribute their profits, Switzerland would have collected tax while other countries which were signatories to tax conventions with Switzerland would have given up revenues in cases where they ought not to.

It was also brought out to the attention of the Committee that holding companies were not the only medium for tax abuse, operating companies also posed a real problem. The United States delegation gave examples of sale companies, licensing companies and service companies in Switzerland engaged in active business activities outside Switzerland. The German delegation pointed out that the problems referred to exist independently of tax treaties. However, the French delegation noted that Swiss operating companies obtained a tax exemption in France as a result of the tax treaty between the two countries, and that tax conventions were a major factor in the problem.

The Swiss opposition however did not prevent the US and Danish delegation from preparing a draft memorandum which served as basis for the discussion of the methods of preventing abuse of tax conventions. The memorandum was originally drafted by the Danish delegation but extensively revised by the US delegation under the supervision of Surrey on December 14, 1962.

\section{Conclusion}

The origins of the STP can be traced back to the very beginnings of the international tax regime. In 1918, the US adopted the foreign tax credit rather than an exemption to relieve double taxation, and justified it in part by relying on the idea that cross border income should not be exempted from tax (as happens under an exemption system if there is no source country tax). ${ }^{16}$ In 1927, the first League of Nations model imposed a withholding tax on interest that was refundable if the taxpayer could show that a tax had been paid to the residence jurisdiction. At the same time the commentary to the model explicitly endorsed the STP:

"From the very outset, [the drafters of the model convention] realized the necessity of dealing with the questions of tax evasion and double taxation in co-ordination with each other. It is

\footnotetext{
${ }^{16}$ In justifying the foreign tax credit, its architect T.S. Adams wrote that "the state which with a fine regard for the rights of the taxpayer takes pains to relieve double taxation, may fairly take measures to ensure that the person or property pays at least one tax." Thomas S. Adams, Interstate and International Double Taxation, in Lectures on Taxation 101, 112-13 (Roswell Magill ed., 1932).
} 
highly desirable that States should come to an agreement with a view to ensuring that a taxpayer shall not be taxed on the same income by a number of different countries, and it seems equally desirable that such international cooperation should prevent certain incomes from escaping taxation altogether. The most elementary and undisputed principles of fiscal justice, therefore, required that the experts should devise a scheme whereby all incomes would be taxed once and only once." 17

However, these ideas took a long time to implement in practice. The foreign tax credit only applied the STP to outbound and not to inbound investment, and the combination with deferral meant that much of the foreign source income of US multinationals was not currently taxed. The interest provision from the 1927 model was never implemented.

Like the arm's-length principle which was invented in the 1930s but only fully implemented when the US adopted the first detailed transfer pricing regulations in 1968, the STP was first implemented by the US under Surrey's leadership. The first author has explained elsewhere how Subpart F was designed to apply the STP to outbound transactions, because in 1962 income that was still eligible for deferral under Subpart F was very unlikely not to be subject to similar levels of source country taxation. ${ }^{18}$ In this article, we show how Surrey applied the STP in practice to inbound transactions and how he began pushing the OECD in the same direction. This is the effort that ultimately bore fruit in the original BEPS project and in the TCJA, which with all their flaws are direct attempts to implement the STP. The current BEPS 2.0 project builds on this distinguished lineage. Thus, it can be said that while Surrey did not invent the STP as a theoretical construct, he was the first to implement it in practice, and all subsequent efforts to do so build on his pioneering work.

\footnotetext{
${ }^{17}$ For the history of this formulation see Mazzoni, Present at the Creation, supra.

${ }^{18}$ Avi-Yonah, All of a Piece Throughout: The Four Ages of U.S. International Taxation, 25 Virginia Tax Rev. 313 (2005); Avi-Yonah and Fishbien, Once More, With Feeling: TRA17 and the Original Intent of Subpart F, 157 Tax Notes 959 (Nov. 13, 2017).
} 